\title{
The Role of Attached and Free-Living Bacteria in Biodegradation in Karst Aquifers
}

\author{
Roger Painter ${ }^{1, *}$, Tom Byl ${ }^{1,2}$, Lonnie Sharpe ${ }^{1}$, Ahmad Kheder ${ }^{1}$ and Justin Harris ${ }^{1}$ \\ 1 Civil and Environmental Engineering, Tennessee State University, Nashville, TN 37209, USA; \\ E-Mails: tdbyl@yahoo.com (T.B.); 1sharpe@tnstate.edu (L.S.); ahmadk19@gmail.com (A.K.); \\ justinvaughnharris@gmail.com (J.H.) \\ 2 United States Geological Survey, Nashville, TN 37211, USA \\ * Author to whom correspondence should be addressed; E-Mail: rpainter@tnstate.edu; \\ Tel.: +1-615-963-5388; Fax: +1-615-963-5902.
}

Received: 15 September 2011; in revised form: 7 November 2011 / Accepted: 22 November 2011 / Published: 8 December 2011

\begin{abstract}
Natural attenuation of groundwater contamination occurs at some level for all aquifers impacted with organic contaminants. The issues regarding natural attenuation are whether it takes place at a sufficient rate to be protective of human health and the environment. Implementation of a Monitored Natural Attenuation (MNA) remedial alternative for groundwater requires parties responsible for the contamination to demonstrate to regulators and the public that MNA is protective at a given site. Analysis of MNA for remediation of karst aquifers is hampered by a lack of understanding of biodegradation in karst environments. The lack of studies examining biodegradation in karst aquifers may in large part be due to the widespread perception that contaminants are rapidly flushed out of karst aquifers resulting in insufficient residence times for contaminants to biodegrade. In highly developed and well-connected conduit systems, the rate of contaminant migration is perceived to be much faster than the rate of biodegradation. This perception of contaminant transport is largely incorrect. Tracer studies for karst aquifers often indicate that these aquifers are characterized by diverse flow regimes and storage capabilities. Additionally, it is also believed that if bioremediation in bedrock aquifers is dependent upon contact between surface-attached bacteria and contaminants, then bioremediation would be limited by the low surface-area-to-volume ratio (SA/V) of karst aquifers. A quantitative basis, however, for accepting or rejecting the assumption that attached bacteria dominate the biodegradation process in karst conduits has not been shown. The objective of this research was to determine if free-living karst bacteria from contributed as much to toluene
\end{abstract}


biodegradation as attached bacteria. This is an important area of research. Research indicates bacteria are both attached and free-living in karst aquifers and it is unrealistic to think that only the attached bacteria facilitate biodegradation. The groundwater use in all tests was taken from a karst aquifer know to be impacted by BTEX. The resulting first-order rate constants were computed to be 0.014 per hour for the open system and 0.0155 per hour for the packed reactor system. Biodegradation of toluene in flow-through laboratory karst systems of varying $\mathrm{SA} / \mathrm{V}$ indicated that the observed biodegradation of toluene was attributable to free-living karst bacteria and not limited by low SA/V in karst. This was evidenced by the fact that the systems with five-fold variation in SA/V were shown to have observed pseudo first order reaction rate constants that differed by only $7.0 \%$. If attached bacteria were primarily responsible for biodegradation and limiting, a proportional difference in the observed rates relative to the difference in surface area would be expected.

Keywords: karst; biodegradation; attached; free-living; bacteria

\section{Introduction}

The lack of studies examining biodegradation in karst aquifers may be due to the widespread perception that contaminants are rapidly flushed out of karst aquifers. Another reason for the lack of studies may be the inherent difficulties in creating controlled experiments in karst environments. In highly developed and well-connected conduit systems, the rate of contaminant migration is expected to be much faster than the rate of biodegradation [1,2]. However, the belief that contaminants are rapidly flushed out of karst aquifers is a popular misconception. Tracer studies suggest that large volumes of water may be trapped in fractures along bedding planes and other features isolated from active groundwater flow paths in karst aquifers [3]. In areas isolated from the major conduit flow paths, contaminant migration may be slow enough that biodegradation could reduce contaminant mass if favorable microorganisms, food sources, and geochemical conditions are present [4-6]. Researchers have also implied that natural bioremediation in karst or fractured rock is unlikely to occur because of the microbiological characteristics of karst aquifers; small microbial populations and low surface-area-to-volume ratio (SA/V). Typical microbial numbers for material from unconsolidated aquifers have been reported to range from $1 \times 104$ to $1 \times 107$ cells per milliliter (cells/mL) [7]. Studies have shown that water from bedrock (granite and karst) aquifers also may contain microbial populations within this range. For example, total microbial populations of $9.7 \times 105$ to $8.5 \times 106$ cells $/ \mathrm{mL}$ and heterotrophic bacteria populations of $3.5 \times 103$ to $5.0 \times 105$ cells $/ \mathrm{mL}$ were detected in ground-water samples collected from a gasoline-contaminated karst aquifer in Missouri [8]. Greater than 70 percent of bacteria in consolidated aquifers are attached to solid surfaces. This fact may have led to the assumption that natural bioremediation in karst conduits is negligible because contact between attached bacteria and contaminants would be limited by the SA/V ratio.

Research currently underway at Tennessee State University focuses on modeling biodegradation of contaminants in karst systems. The research presented in this paper compares the biodegradation of toluene by attached and free-living bacteria in two laboratory karst systems. This is an important area 
of research [9-11]. Research indicates bacteria are both attached and free-living in karst aquifers and it is unrealistic to think that only the attached bacteria facilitate biodegradation. Conservative tracer studies, sterile controls and quantified toluene biodegradation were used to mathematically determine biodegradation rates for two laboratory karst systems representing different $\mathrm{SA} / \mathrm{V}$ ratios. The toluene biodegradation results from the laboratory karst systems were analyzed in terms of chemical reaction kinetics and mass transfer principles.

\section{Materials and Methods}

Laboratory flow through karst microcosms were constructed using a 20-liter glass reservoir and four 1-liter volumetric flasks connected in series. One system was packed with a sufficient number of glass spheres to increase the surface-area-to-volume five-fold in the packed system as compared to the unpacked system. Water was pumped into both systems by using a high-performance peristaltic pump. A stirred injection cell (10 mL volume) was placed at the entrance of each replicate system for the injection of dye or toluene. During the conservative dye tracer studies Rhodamine dye was simultaneously injected into the stirred injection cells of the packed and unpacked systems. The Rhodamine concentration at the discharge port was monitored through time by collecting samples at 1-2 hour time intervals over a 4-day period. A fluorometer was used to quantify the Rhodamine in the water samples. The lower detection limit on the fluorometer was established at 100 parts per trillion.

Toluene was selected as the experimental contaminant because it is a component in most fuels and because previous work indicated Pseudomonad bacteria, which are heterotrophic aerobic bacteria (HAB), from the Kentucky site could grow using toluene as a food source. The biodegradation experiments used water containing live bacteria collected from a 120-foot-deep well completed in a karst aquifer in south-central Kentucky. Bacteria counts ranged from approximately 700,000 bacteria per milliliter to 1.2 million depending on the well and sample collection time. These bacteria counts were derived using two methods, direct counts and BART growth tests, and the results of the two tests were within 20 percent of each other. Bacteria from the fuel contaminated part of the karst aquifer had a 5\% lighter buoyant density and a wider range of sizes than the bacteria from the non-contaminated well. Additionally, bacteria isolated from fuel contaminated ground-water samples readily grew with dissolved gasoline as the only source of food. Static microcosms set up using aerated raw karst water and spiked with Toluene at $1 \mathrm{mg} / \mathrm{L}$ established a pseudo first order biodegradation rate constant of $0.0186 \mathrm{hr}^{-1}$. Sterile control microcosms had less than $10 \%$ toluene loss over the same time period [12-14].

Before the tracer study was initiated, the experimental systems were sterilized with bleach. The bleach was neutralized with sterile sodium thiosulfate. During the conservative dye tracer study, a constant flow rate of approximately 3 milliliters per minute $(\mathrm{mL} / \mathrm{min})$ was established for both systems. The water flowing through the abiotic system was sterile water that had a $\mathrm{pH}$ of 10 . Previous work indicated that elevating the $\mathrm{pH}$ to 10 maintains an abiotic system. At the beginning of the tracer study, 300 micrograms $(\mu \mathrm{g})$ of Rhodamine dye $(1,500 \mu \mathrm{g}$ of $20 \% \mathrm{wt} / \mathrm{wt}$ solution) was injected into each stirred injection cell. The Rhodamine concentration at the discharge port was monitored through time by collecting samples over a 4-day period.

Before the toluene biodegradation study was initiated toluene was injected into an abiotic system to investigate loss of toluene to vaporization and or adsorption, The experimental systems were sterilized 
with bleach. The bleach was neutralized with sterile sodium thiosulfate. Filter-sterilized toluene $(87 \mu \mathrm{g})$ dissolved in 100 micro liters $(\mu \mathrm{L})$ of methanol was delivered into the injection cell and pushed through the abiotic system with sterile water that had a $\mathrm{pH}$ of 10 . Previous work indicated that elevating the $\mathrm{pH}$ to 10 maintains an abiotic system. Toluene concentration was monitored at the discharge port over the next 5 days. Water samples were collected in clean $40-\mathrm{mL}$ volatile organic compound (VOC) vials every 1 to 4 hours. The water samples were immediately analyzed on a gas chromatograph (GC) equipped with a purge-and-trap system, silica-film capillary column, argon-carrying gas, and micro-argon ionization detector.

The karst groundwater-containing live bacteria was then pumped through the system for four days to establish a bio-film on the glass surfaces. An $87-\mu \mathrm{g}$ aliquot of toluene was then injected into the biotic system in the same manner as for the abiotic test. In order to document the presence of attached bacteria, glass slides were suspended in both the packed and unpacked systems. The suspended slides were removed prior to and at the end of the experiments and viewed using an epifluorescent microscope and the direct count method [15].

The advection, dispersion equation for the conservative tracer is:

$$
\frac{\partial C}{\partial t}=D_{a} \frac{\partial^{2} C}{\partial z^{2}}-v \frac{\partial C}{\partial z}
$$

The solution of Equation 1 for Dankwerts boundary conditions for an open-open system gives the following relationship between the Peclet number $\left(\mathrm{P}_{\mathrm{e}}\right)$ for the non-ideal flow system, the mean residence time, and the variance $[16,17]$ :

$$
\begin{aligned}
t_{m} & =\left(1+\frac{2}{P e}\right) \tau \\
\frac{\sigma^{2}}{P_{e}^{2}} & =\frac{2}{P_{e}}+\frac{8}{P_{e}^{2}}
\end{aligned}
$$

Values of $\sigma^{2}$ and $t_{m}$ from the dye study are used to estimate $P_{e}$ and $\tau$ and these parameters are used to estimate the extent to which the toluene flowing through the system is biodegraded. The experimental value of for the fraction of toluene biodegraded (X) was obtained by numerically integrating the toluene concentration versus time data.

The equation for the toluene undergoing biodegradation as it flows through the system is:

$$
\frac{D_{a}}{U} \frac{d C_{A}}{d z^{2}}-\frac{d C_{A}}{d z}+\frac{r_{A}}{U}=0
$$

This equation is linear for zero or first order kinetics and thus can be solved analytically. The solution for assumed pseudo first order biodegradation kinetics is [18]:

$$
X=1-\frac{4 q e^{\left(P_{e} / 2\right)}}{(1+q)^{2} e^{\left(P_{e} q / 2\right)}-(1-q)^{2} e^{\left(-P_{e} q / 2\right)}}
$$


Where

$\mathrm{X}=$ the fraction of toluene biodegraded

$q=\sqrt{1+4 D_{A} / P_{e}}$

$\mathrm{D}_{\mathrm{A}}=\mathrm{k}^{\prime} \mathrm{t}$

And

$\mathrm{k}^{\prime}=$ the pseudo first biodegradation rate constant

The experimental values for the conversion and the unique Peclet numbers from the conservative tracer studies allows for the calculation and comparison of the "observed" values for $\mathrm{k}$ ' for the packed and unpacked systems.

\section{Results and Conclusions}

The RTD for each system was calculated from the conservative dye study. The data were numerically integrated to determine the mean residence time $\left(t_{m}\right)$ and the variance $\left(\sigma^{2}\right)$ for the packed and unpacked laboratory karst systems. These parameters where then used to calculate the Peclet numbers, which are an indicator of the dispersion as the solute moves through the system. The results for the mass balances for the tracer and toluene for the abiotic and biotic studies are presented in Table 1.

Table 1. Calculated results for tracer and toluene mass balances.

\begin{tabular}{lcccccc}
\hline & \multicolumn{2}{c}{ Tracer Study } & \multicolumn{2}{c}{ Toluene (Abiotic) } & \multicolumn{2}{c}{ Toluene (Biotic) } \\
\hline & Open & Packed & Open & Packed & Open & Packed \\
\cline { 2 - 7 } Mass Injected $(\mu \mathrm{g})$ & 300.0 & 300.0 & 87.0 & 87.0 & 87.0 & 87.0 \\
Mass Recovered $(\mu \mathrm{g})$ & 287.0 & 304.0 & 91.0 & 89.0 & 60.0 & 69.0 \\
Percent Recovery & 95.6 & 100 & 100 & 100 & 68.9 & 79.3 \\
Mean Residence Time (hr) & 15.3 & 27.4 & & & & \\
Peclet Number & 13.7 & 15.8 & & & & \\
$\mathrm{X}$ (Equation 5) & - & - & - & - & 0.31 & 0.21 \\
$\mathrm{k}^{\prime}$ (Equation 5) $\mathrm{hr}^{-1}$ & - & - & - & - & 0.0140 & 0.0155 \\
\hline
\end{tabular}

The results of the conservative dye study are shown in Figure 1. The results of the conservative dye study are shown in Figure 1. The concentration versus time response curve for the toluene undergoing biodegradation is shown in Figures 2 and 3 for the unpacked and packed systems respectively. The response curves for the abiotic toluene tests are also shown in Figures 2 and 3. The mass of toluene recovered in the effluent is proportional to the area beneath the response curves and the decrease in area for the biotic test was associated with the fraction of toluene undergoing biodegradation. 
Figure 1. Schematic of flow-through microcosms.

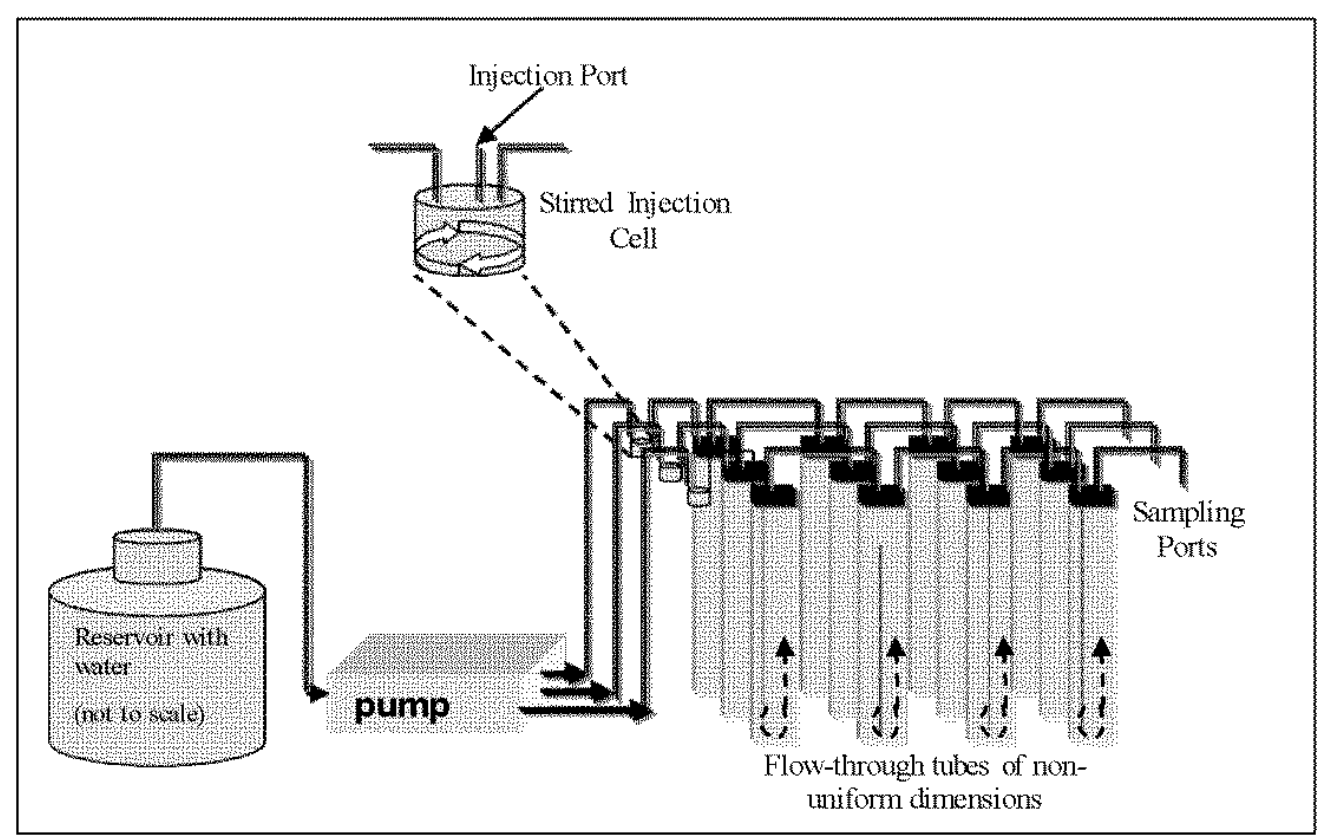

Figure 2. Dye study results.

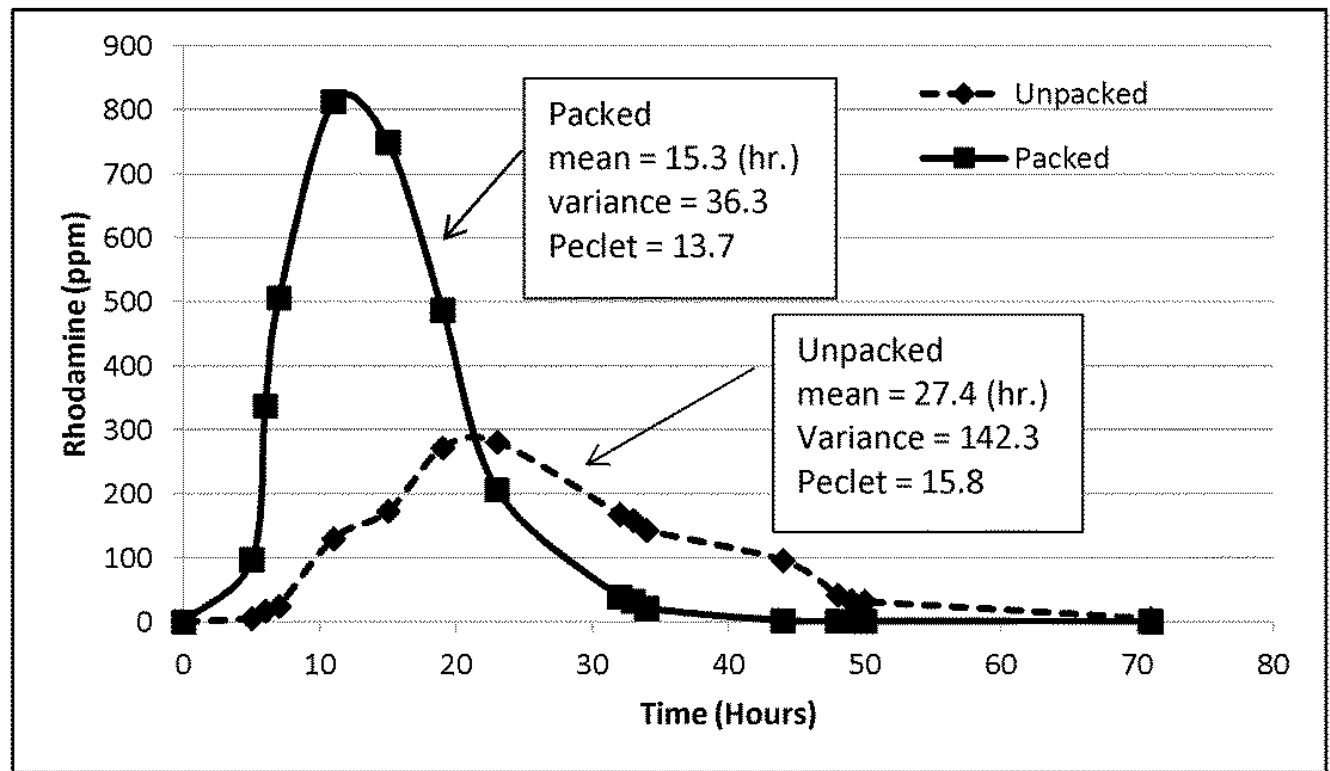

Karst groundwater from a fuel impacted aquifer containing live bacteria was then pumped through the laboratory systems for 4 days to establish a biofilm on the glass surfaces. Bacteria counts using MPN and microscopic methods were used to confirm that bacteria covered the glass surfaces and were suspended in the water at the beginning and end of the experiments (Figures 3 and 4). 
Figure 3. Toluene degradation results for unpacked system.

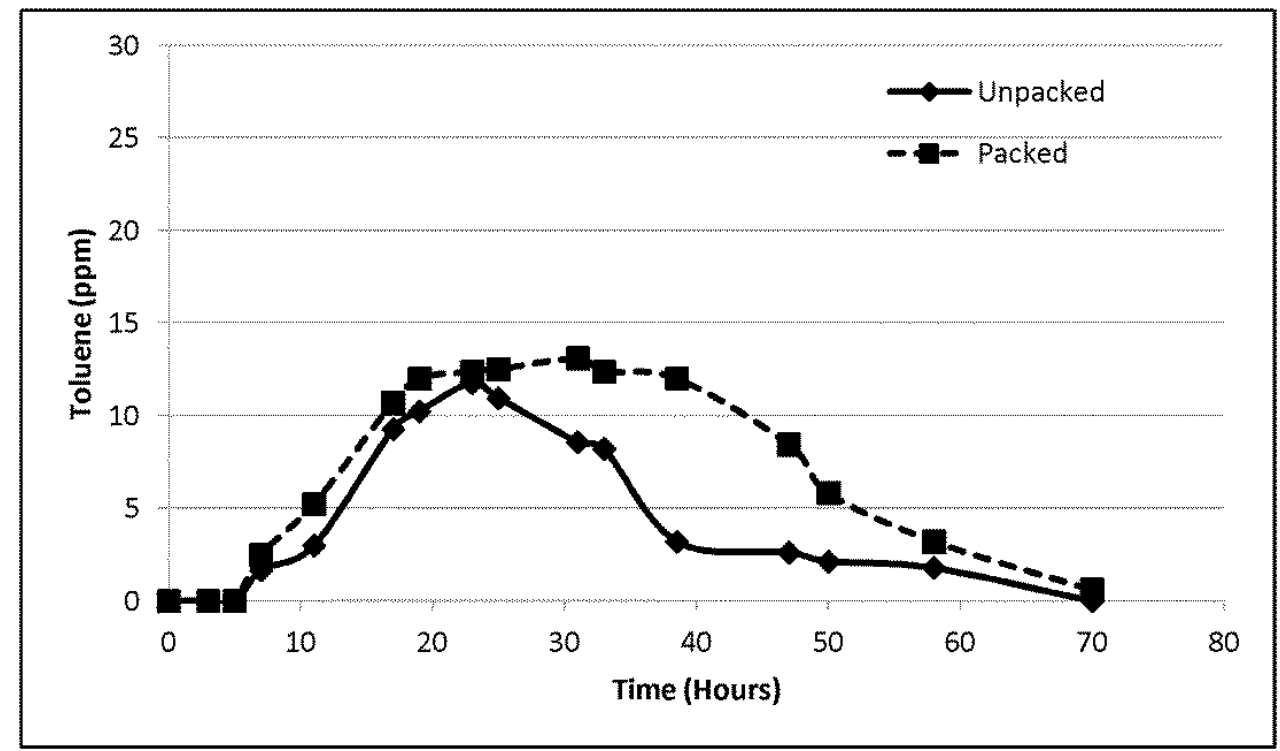

Figure 4. Toluene degradation results for packed system.

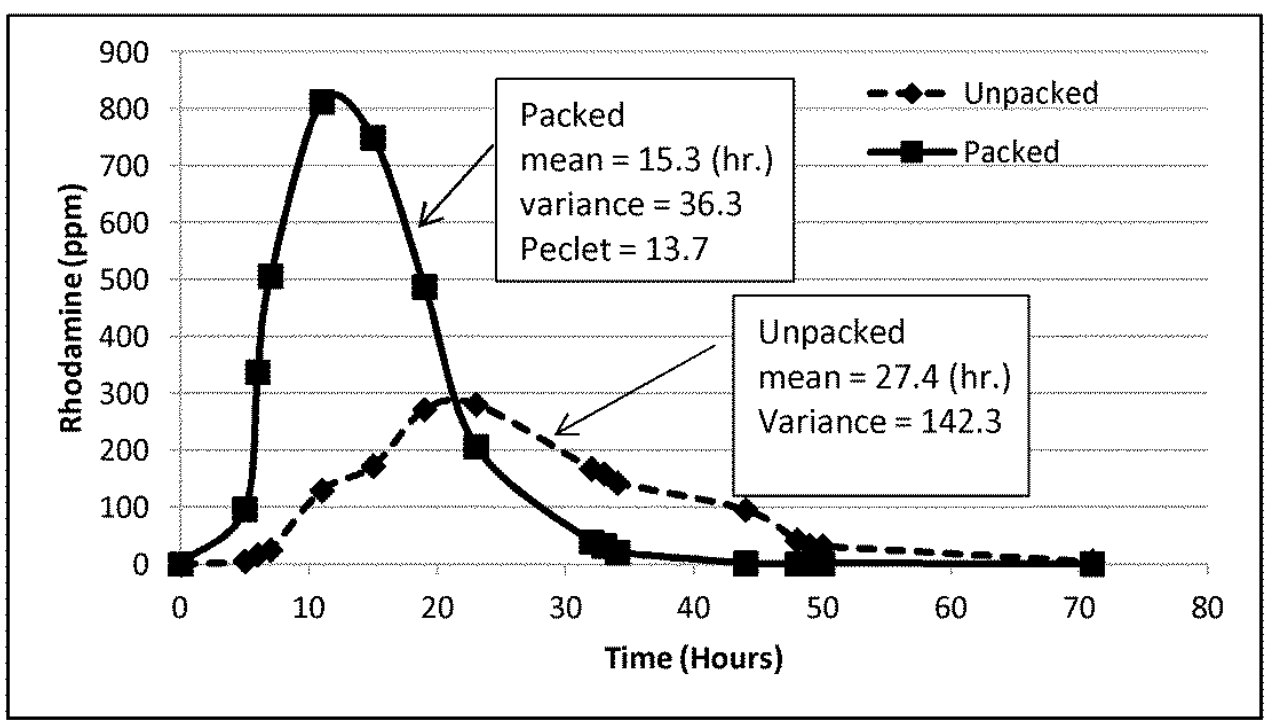

Numerical integration of the resulting effluent tracer and toluene concentration versus time data indicated quantitative recovery of the tracer and toluene for the abiotic studies and recovery of $61 \mu \mathrm{g}$ toluene from the unpacked reactor and $69 \mu \mathrm{g}$ toluene from the packed reactor. The resulting observed toluene biodegradation conversion fraction (X) for the packed and unpacked systems was 0.21 and 0.31 , respectively. These conversion values where used in the Equation 5 to calculate the observed biodegradation rate constants $\left(\mathrm{k}^{\prime}\right)$. The values of $\mathrm{k}^{\prime}$ were 0.014 per hour and 0.0155 per hour for the packed and unpacked systems, respectively. Biodegradation of toluene in flow-through laboratory karst systems of varying $\mathrm{SA} / \mathrm{V}$ indicated that the observed biodegradation of toluene was attributable to free-living bacteria and not limited by low SA/V in karst. This was evidenced by the fact that the systems with five-fold variation in $\mathrm{SA} / \mathrm{V}$ were shown to have observed pseudo first order reaction rate constants that differed by only $7.0 \%$. If attached bacteria were primarily responsible for biodegradation 
and limiting, a proportional difference in the observed rates relative to the difference in surface area would be expected. The observed biodegradation rate reflects a half-life for toluene of about 50 hours. Thus, dissolved toluene that resided for several days in a karst conduit with characteristics similar to those in this study could experience substantial biodegradation regardless of interaction with the surface area. The suspended slides were removed prior to and at the end of the experiments and viewed using an epifluorescent microscope and the direct count method. Figures 5 and 6 shown below are representative of the photographs of the glass surfaces.

Figure 5. (a) Bacteria (white objects) attached to the surface of the glass after 3 days of pumping water through the system (400× magnification, epifluorescent); and (b) close up of a bacteria cluster on the surface of the glass $(800 \times$ magnification, epifluorescent).

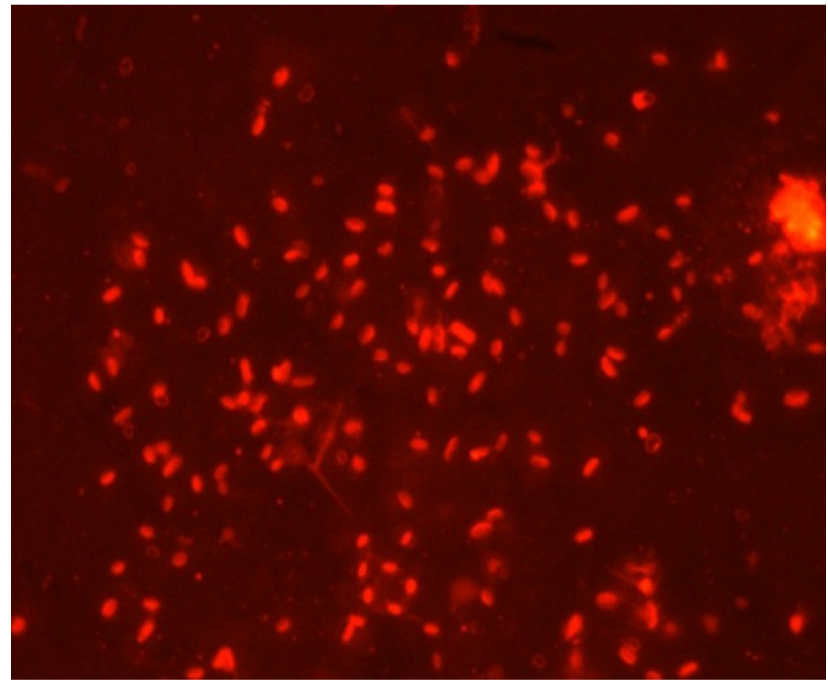

(a)

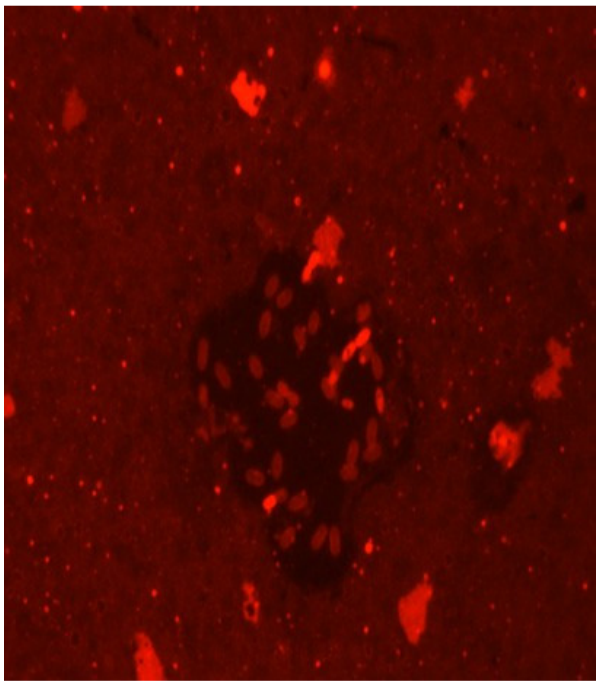

(b)

Figure 6. Free-living bacteria (dark objects) collected from the water column after 3 days. Flagella can be observed attached to the rod-shaped bacteria $(1,000 \times$ magnification, bright field).

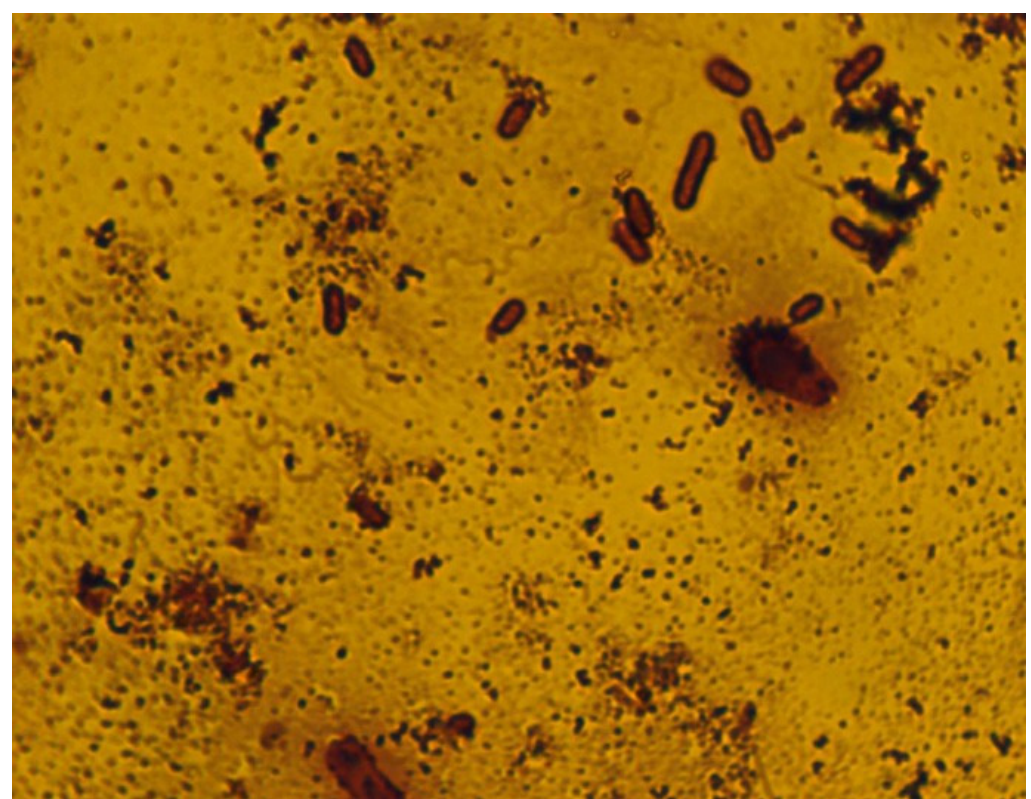




\section{References}

1. Poty, J.-C.F.; Mahler, B.; Drogue, C. Colonization by aerobic bacteria in Karst: Laboratory and in situ experiments. Ground Water 2004, 42, 526-533.

2. Ryan, M.; Meiman, J. An examination of short-term variations in water quality at a karst spring in Kentucky. Ground Water 1996, 34, 23-30.

3. Field, M.S. Karst hydrology and chemical contamination. J. Environ. Syst. 1993, 22, 1-26.

4. Byl, T.D.; Painter, R. Microbial adaptations to Karst aquifers with contaminants. In Proceedings of American Water Resources Association (AWRA) Annual Water Resources Conference, Seattle, WA, USA, 9-12 November 2009.

5. Harvey, R.W.; Barber, L.B., II. Association of free-living bacteria and dissolved organic compounds in a plume of contaminated groundwater. J. Contam. Hydrol. 1992, 9, 91-103.

6. Harvey, R.W.; Smith, R.L.; George, L. Effect of organic contamination upon microbial distributions and heterotrophic uptake in a Cape Cod, Mass., aquifer. Appl. Environ. Microbiol. 1984, 48, 1197-1202.

7. Ghiorse, W.C.; Wilson, J.T. Microbial ecology of the terrestrial subsurface. Adv. Appl. Microbiol. 1988, 33, 107-172.

8. O'Connor, J.T.; Brazos, B.J. The response of natural ground water bacteria to ground water contamination by gasoline in a Karst region. In Proceedings of the Conference on Hazardous Waste Research, Kansas State University, Manhattan, KS, USA, 1991; Erickson, L.E., Ed.; pp. 81-293.

9. Lehman, R.M.; Colwell, F.S.; Bala, G.A. Attached and unattached microbial communities in a simulated basalt aquifer under fracture- and porous-flow conditions. Appl. Environ. Microbiol. 2001, 67, 2799-2809.

10. Holm, P.E.; Nielsen, P.H.; Albrechtsen, H.; Christensen, T.H. Importance of unattached bacteria and bacteria attached to sediment in determining potentials for degradation of xenobiotic organic contaminants in an aerobic aquifer. Appl. Environ. Microbiol. 1992, 58, 3020-3026.

11. Doong, R.-A.; Chen, T.-F.; Wu, Y.-W. Anaerobic dechlorination of carbon tetrachloride by free-living and attached bacteria under various electron-donor conditions. Appl. Microbiol. Biotechnol. 1997, 47, 317-323.

12. Byl, T.D.; Hileman, G.E.; Williams, S.D.; Farmer, J.J. Geochemical and microbial evidence of fuel biodegradation in a contaminated Karst aquifer in Southern Kentucky, June 1999; U.S. Geological Survey Water-Resources Investigations Report 2001-4011. In Proceedings of U.S. Geological Survey Karst Interest Group Proceedings, St. Petersburg, FL, USA, 13-16 February 2001; Kuniansky, E.L., Ed.; pp. 151-156. Available online: http://water.usgs.gov/ogw/karst/kigconference/proceedings.htm (accessed on 27 January 2005).

13. Byl, T.D.; Hileman, G.E.; Williams, S.D.; Metge, D.W.; Harvey, R.W. 2002. Microbial strategies for degradation of organic contaminants in Karst; U.S. Geological Survey Open-File Report 2002-89. In Proceedings of U.S. Geological Survey Artificial Recharge Workshop Proceedings, Sacramento, CA, USA, 2-4 April 2002; Aiken, G.R., Kandinsky, E.L., Eds.; pp. 61-62. Available online: http://water.usgs.gov/ogw/pubs/ofr0289/ (accessed on 27 January 2005). 
14. King, L.K.; Painter, R.D.; Byl, T.D. Adaptation of the Residence Time Distribution (RTD) - biodegradation model to quantify 2C-12 peroxide-enhanced fuel biodegradation in a single Karst well; USGS Scientific Investigation Report 2005-5160. In Proceedings of U.S. Geological Survey Karst Interest Group Proceedings, Rapid City, SD, USA, 12-15 September 2005; Kuniansky, E.L., Ed.; pp. 174-179. Available online: http://pubs.usgs.gov/sir/2005/5160/ (accessed on 1 November 2011).

15. Standard Methods for the Examination of Water and Wastewater, 19th ed.; Clesceri, L.S., Eaton, A.D., Greenberg, A.E., Franson, M.A.H., Eds.; American Public Health Association, American Water Works Association, Water Environment Federation: Washington, DC, USA, 1996.

16. Danckwerts, P.V. Continuous flow systems. Distribution of residence times. Chem. Eng. Sci. 1952, 50, 3857-3866.

17. Shinnar, R.; Naor, P. Residence time distribution in systems with internal reflux. Chem. Eng. Sci. 1967, 22, 1369-1381.

18. Tchobanoglous, G.; Burton, F.L.; Stensel, D.H. Wastewater Engineering, Treatment and Reuse, 4th ed.; McGraw Hill: Columbus, OH, USA, 2003; p. 279.

(C) 2011 by the authors; licensee MDPI, Basel, Switzerland. This article is an open access article distributed under the terms and conditions of the Creative Commons Attribution license (http://creativecommons.org/licenses/by/3.0/). 